\title{
The Implementation of The Employee Leaving Input System of PT. Prima Sejati Sejahterah Boyolali
}

\author{
$1^{\text {st }}$ Risma Nur Hanifah, $2^{\text {nd }}$ Nendy Akbar Rozaq Rais \\ ${ }^{1,2}$ Institut Teknologi Bisnis AAS Indonesia Surakarta \\ 1,2Jl. Slamet Riyadi No. 361 Windan, Makamhaji, Kartasura, Sukoharjo, Indonesia \\ ${ }^{1}$ rismahanifah2@gmail.com, ${ }^{2}$ ab.terate@gmail.com
}

\begin{abstract}
PT. PAN BROTHER is a multinational company that produces textiles headquartered in Jakarta, Indonesia. This company was founded in 1969. This company produces various kinds of clothing. Currently, PT. PAN BOTEHR, especially the branch in Boyolali, namely PT. Prima Sejati Sejahtera has conducted attendance by using a finger print machine and a computerized scanner. Employees who wish to take annual leave, maternity leave, official permits, and sick leave are already using a web-based system, by means of employees inputting attendance on a computer provided by the company. However, there are still employees who lack knowledge of science and technology and are still an obstacle to implementing the web-based system. This system can actually be accessed using a smart phone, so that employees do not need to ask attendance staff for help when inputting leave. And to recap the attendance report of HRD employees must also look for employee leave documents that are still in paper files, so that this can slow down the withdrawal of reports on a monthly basis. With this problem, the Company made an innovation by creating an on line-based web application for inputting employee leave and the author also conducted research on the application of this web-based system using literature study and field studies in field objects. It is hoped that with this research, the system can be used by all employees to be more effective in inputting absences due to leave and can help alleviate the performance of HRD staff to be more flexible and efficient and reduce absenteeism reporting errors due to employee leave.
\end{abstract}

Keywords: information systems, attendance, leave, web, employees

\section{INTRODUCTION}

Along with the rapid development of technology, webbased information systems are used as a means of improving information. This utilization will facilitate a job such as faster data processing, more precise decisions, save time and costs.

The problems faced by PT. Prima Sejati Sejahtera Boyolali is that all data processing, especially in the HRD department, is still done manually where in the process of making leave requests still using Microsoft Word or Excel and for employee leave reports, they still use paper which is stored as employee leave report documents. To make it easier for employees to do the leave process and get complete and detailed information related to leave, the company created an online information system. With the online web for inputting employee leave, and pulling leave reports, HRD employees no longer need to use document papers as reports.

Every company is always faced with problems in carrying out an activity. These problems require more indepth attention and handling so that these problems can be resolved properly. Based on the research that has been done, it can be defined the problem to apply for effective leave at PT. Prima Sejati Sejahtera Boyolali, namely: Is a computerized system really needed to apply for leave both by the employee who submitted it, the HRD who processed it, and the boss who allowed it?

Limiting a problem is used to avoid irregularities or widening the subject matter so that the research is more focused and makes it easier to discuss so that the research objectives will be achieved. Some of the limitations of the problem in this study are as follows: This study focuses on the application of the employee leave input system at PT. Prima Sejati Sejahtera Boyolali, In this system, adding, editing and deleting data is only done by the designated admin and employees who have the account. The author does not discuss company data. The objectives to be achieved by the authors of the research conducted on the employee leave filing system at PT. Prima Sejati Sejahtera Boyolali is with the results of research made by the author regarding the use of Information Technology, it is hoped that it can be used effectively and efficiently for filing leave in the existing system, so that it can make it easier to apply for leave that was previously still manual or not computerized. The author also hopes that the computerized leave application system can provide added value and create an effective and efficient service to the company. And provide intensive training for system users to become reliable users in system application.

\section{RESEARCH METHODS}

$\mathrm{n}$ this research method there are 2 types of methods, namely data collection methods and systems development methods.

\subsection{Data Collection Methods}

The following data collection methods are as follows:

a. Interview

Interviews were carried out by interviewing directly related parties, which is useful for obtaining information and data needed for the design and construction of the system to be made

b. Observation

In this method of observation (observation), direct field visits and research are carried out to obtain and collect the required data. These observations were carried out at PT. Prima Sejati Sejahtera. From these observations, the submission process and information regarding leave manually, such as coming directly to the HRD department, and data are not stored in a structured manner, thus these deficiencies need to be resolved, which will satisfy the company's employees. Observations are made by collecting data and information needed in system design and development. 
International Journal of Computer and Information System (IJCIS)

Peer Reviewed - International Journal

Vol : Vol. 02, Issue 01, February 2021

e-ISSN : 2745-9659

https://ijcis.net/index.php/ijcis/index

\section{c. Literature study}

Literature study is carried out by searching for books related to research, scientific works and journals, articles, both in libraries and on the internet. Data originating from the internet, which is used as a reference in the preparation of this final project, among others: relating to the introduction of information systems.

\subsection{Systems Development Method}

The following methods in system development are as follows: System Planning : The stage where all the work and activities that were carried out before this application is actually produced, in this stage it is carried out : Feasibility Study, Time Allocation, Scope. System Analysis : At this stage, a system analysis is being carried out at PT. Prima Sejati Sejahtera Boyolali, which is still done manually and identifies the problems that arise, which will get the best solution. The activities carried out in this stage include : Running System Procedure, Decomposition of Current System Functions, Activity Diagram of the Running System, Running System Specifications, Problem, Alternative Problems, System Design.

After conducting the analysis stage, the employee leave system design stage is carried out, by designing and describing the new system processes. Activities carried out in this design stage include : Decomposition of the Proposed System Functions, UML system design, Database Specifications, System Implementation.

Implementation is the process of implementing the Employee Leave Information System application that is built so that users can use it. At this stage, implementation is carried out with several processes, namely Notifying User (Notify User), Training User (User Training), Pairing the System (Install System)

After successfully passing all implementation processes, this means that the Employee Leave Information System application can be used. System Testing : At this stage, the overall program testing or testing of the Karywan Leave Information System application will be carried out. The purpose of this stage is to ensure that this application is truly worthy of publication. At this stage the authors conducted a trial by inputting employee leave using one of the employee data.

Management information system is a planning system part of internal control in business which consists of the use of documents, people, technology, and procedures in management accounting. Management information system is a collection of hardware and software designed to transform data into useful information [1]

In designing a web-based employee leave information system, supporting equipment is needed to streamline and identify each existing database. The equipment that plays a role in the process of making this website is UML. UML (Unified Modeling Language) is one of the most powerful tools in the world of object-oriented systems development. [2] This is because UML provides a visual modeling language that allows system developers to create a blueprint for their vision in a standard, easy-to-understand form equipped with effective mechanisms to share and communicate their designs with others.
Laravel is one of the most popular PHP frameworks and is most widely used worldwide in building web applications ranging from small to large projects. This framework is widely used by web developers because of its performance, features, and scalability. This framework follows the structure of the MVC (Model View Controller), MVC is an application method by separating data from views based on application components, such as data manipulation, controllers, and user interfaces. Another plus is that Laravel is very easy to customize. Because of that simplicity you can create a project structure that meets the demands of the web application to be designed.

A website is a collection of interconnected web pages and their related files. The web consists of pages or pages, and a collection of pages called the homepage. The homepage is in the top position, with related pages at the bottom. Usually each page under the homepage is called a child page, which contains hyperlinks to other pages on the web [3].

Web began to be used for applications that require a lot of user interaction. Web applications are not only used on the internet, but can also be used for intra-organizational purposes. A network of web applications installed in an intra-organizational environment is called an intranet.

PHP is a programming language that allows web developers to create dynamic web applications quickly and easily. PHP stands for "PHP: Hypertext Preprocessor". PHP was pioneered and first introduced around 1994 by Rasmus Lerdorf through its website to find out who has accessed its online summary [4].

PHP is a server-side scripting language that can be integrated with HTML tags. Server-side scripting is the syntax and commands that are run on the server and included in HTML documents. On a dynamic page, PHP functions as a programming language that runs a specific commands, whereas HTML serves as the structure of the web page design.

MySQL is an application or system for managing databases or data management. To save data and information to computers we use data. These grouped data files are called databases, and MySQL is in charge of organizing and managing a table-shaped structure or framework. It is in tables that data are arranged and grouped [5] Similar to PHP, MySQL is a type of software, including open source. Open source software (English: open source software) is a type of software whose source code is open to be studied, modified, improved and distributed. Because of this nature, generally the development is carried out by an open group that aims to develop the software concerned.

\section{III.RESULT AND ANALYSIS}

In the discussion, discussing the results of research in the form of system design as a whole are as follows:

\subsection{Computerized System Analysis}

System analysis is a process that must be carried out to determine the solution to a problem at hand. After the author knows the problems that exist in the leave submission process at PT. Prima Sejati Sejahtera, the authors propose a solution to the problem in the system, 
International Journal of Computer and Information System (IJCIS)

Peer Reviewed - International Journal

Vol : Vol. 02, Issue 01, February 2021

e-ISSN : 2745-9659

https://ijcis.net/index.php/ijcis/index

namely using a computer-based system, and the manual system is only used in storage media for archiving which can be used at any time in the data processing process. Data processing techniques are used, namely a database system that allows each user to request information from the data file at any time.

\subsection{System Design}

This section contains an explanation of system design for building management information system applications.

1. Contex Diagram

The Contex Diagram (CD) for the scholarship acceptance decision support system is as follows:

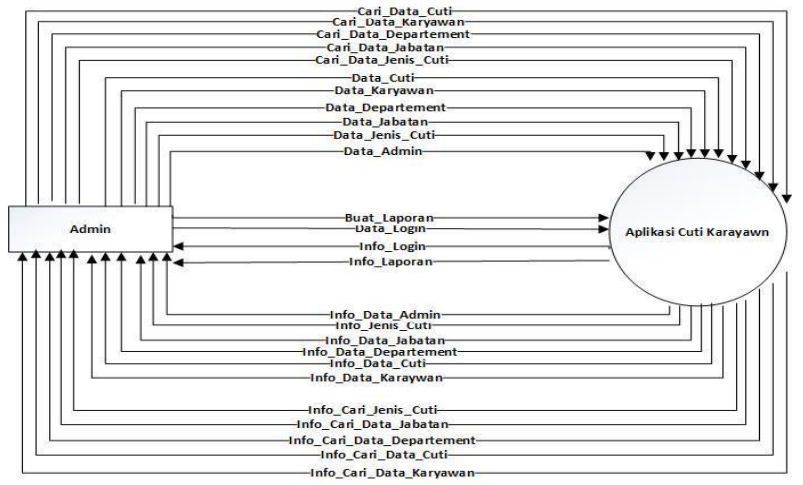

Figure 1. Context Diagram

\section{HIPO}

HIPO (Input Process Output Hierarchy) is a system development tool and system documentation technique in programs. The most important goal of HIPO is to produce correct output and meet user requirements.

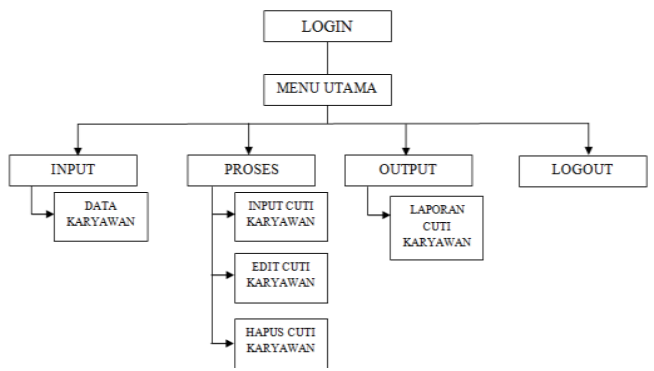

Figure 2. HIPO System

\section{DAD (Data Flow Diagram)}

Data Flow Diagram (DAD) is a flow diagram that describes the flow from data to the system, DAD helps to understand the system in a logical, structured and clear way. The following is DAD level 0 for employee leave input.

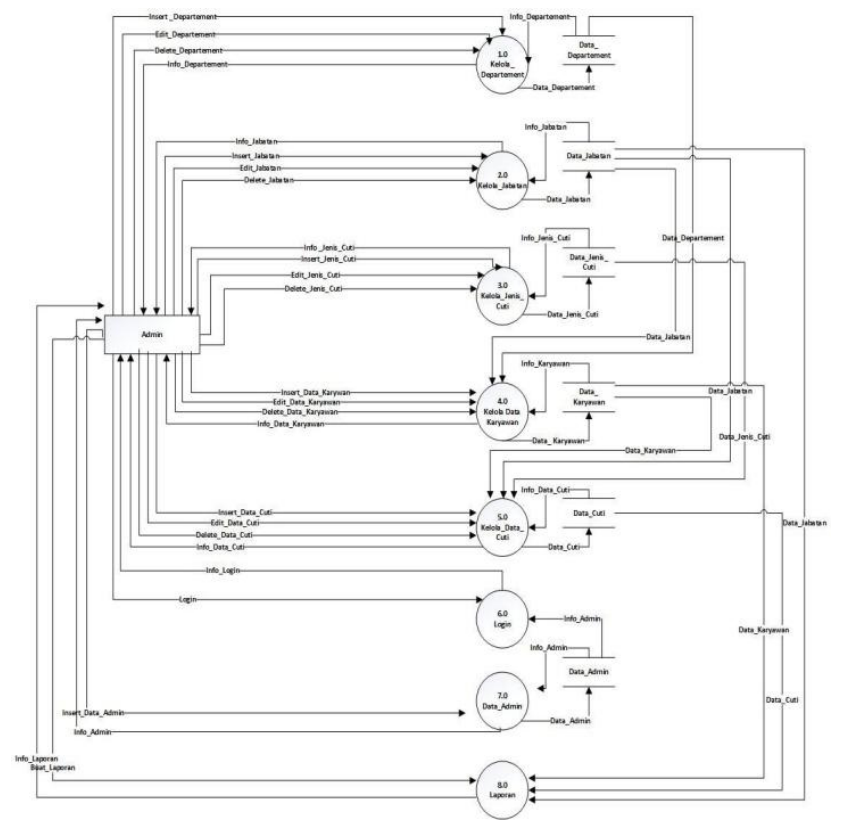

Figure 3. DAD

\subsection{System Implementation}

System implementation is the process of making a system in the form of designing an employee leave input system:

1. Employee leave menu selection dashboard Employee leave menu selection dashboard display.

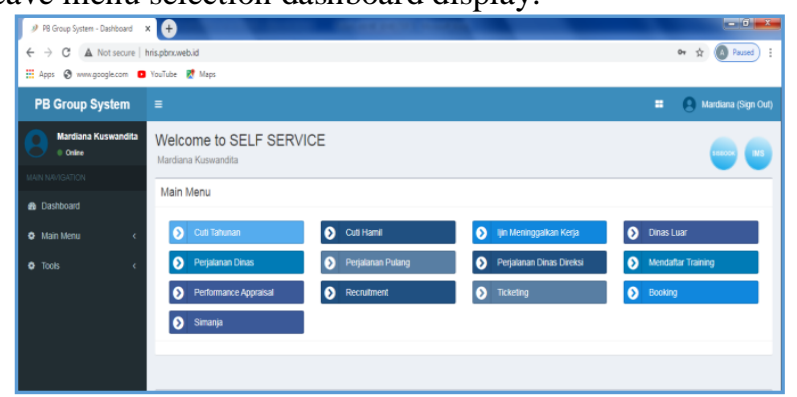

Figure 4. Leave menu selection dashboard

2. Display Employee Leave Data Input

The following is a display on the employee leave data input form as follows

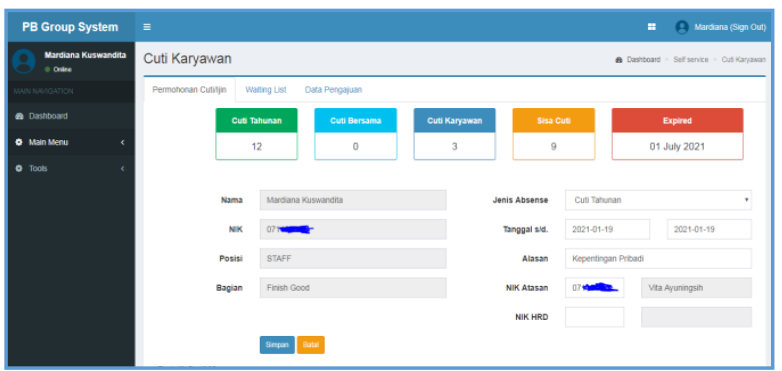

Figure 5. Employee Leave Data Input Form

3. Display Report Results

Display the results of the Employee Leave report 
International Journal of Computer and Information System (IJCIS)

Peer Reviewed - International Journal

Vol : Vol. 02, Issue 01, February 2021

e-ISSN : 2745-9659

https://ijcis.net/index.php/ijcis/index

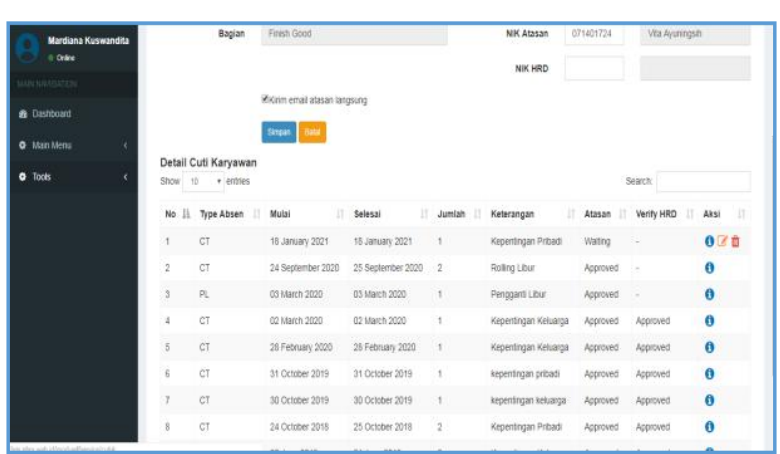

Figure 6. Employee Leave Report

\subsection{System Testing}

Testing is done by two methods, namely testing the implementasi system follow :

\subsection{System Testing}

Testing is a system test process at the end which is also useful for testing the system. There are two system tests, namely the functionality test and the questionnaire test. following the test:

\subsubsection{Functionality Testing}

Functionality testing uses the Black Box, which is useful for knowing the output results in each form in the program system. following the results of the recapitulation.

Table 1. Functionality Test

\begin{tabular}{|c|c|c|l|}
\hline INPUT & FUNGSI & OUTPUT & HASIL \\
\hline Tombol login & $\begin{array}{c}\text { Untuk masuk ke } \\
\text { halaman utama }\end{array}$ & $\begin{array}{c}\text { Menampilkan halaman } \\
\text { utama }\end{array}$ & SesuaiNormal \\
\hline Tombol dashboard & $\begin{array}{c}\text { Masuk untuk memilih } \\
\text { informasi pengguna }\end{array}$ & $\begin{array}{c}\text { Menampilkan halaman } \\
\text { profil }\end{array}$ & SesuaiNomal \\
\hline Tombol pengajuan cuti & $\begin{array}{c}\text { Untuk masuk ke } \\
\text { halaman pengajuan cuti }\end{array}$ & $\begin{array}{c}\text { Menampilakan halaman } \\
\text { pengajuan cuti }\end{array}$ & SesuaiNormal \\
\hline Tombol tambah cuti & $\begin{array}{c}\text { Untuk masuk ke } \\
\text { halaman tambah cuti }\end{array}$ & $\begin{array}{c}\text { Menampilkan halaman } \\
\text { untuk input cuti }\end{array}$ & SesuaiNormal \\
\hline Tombol edit cuti & $\begin{array}{c}\text { Untuk masuk ke } \\
\text { halaman edit cuti }\end{array}$ & $\begin{array}{c}\text { Menampilkan halaman } \\
\text { untuk edit cuti }\end{array}$ & SesuaiNormal \\
\hline Tombol hapus cuti & $\begin{array}{c}\text { Untuk masuk ke } \\
\text { halaman hapus cuti }\end{array}$ & $\begin{array}{c}\text { Menampilkan halaman } \\
\text { untuk hapus cuti }\end{array}$ & SesuaiNormal \\
\hline Tombol logout & $\begin{array}{c}\text { Untuk keluar dari } \\
\text { halaman utama }\end{array}$ & $\begin{array}{c}\text { Menampilkan halaman } \\
\text { login }\end{array}$ & SesuaiNormal \\
\hline
\end{tabular}

\subsubsection{Quizoner Testing}

The following are the stages of questionnaire testing In the process of determining a questionnaire test for this system, several respondents were involved. This can be seen in table 2. Below. From the questionnaire test, it can be concluded that many employees already know this webbased employee leave input system. And many of the employees have entered this employee leave by themselves. With this system, it can be very effective and efficient for admins and superiors. From the SWOT analysis above, it can be concluded that the employee leave input system really helps the company in the employee attendance section. And this system also illustrates that the company is a developed company, thus adding a plus compared to other companies in the same field.

\subsubsection{SWOT analysis}

At this time it can be said that the application "E-Patient RS UNS" is able to answer and solve problems that occur in offline registration or on the old system. With patient characteristics, polyclinic services, types of funding, and doctors currently available can be accommodated by the application "E-Patient UNS Hospital".

Table 2. SWOT Analysis

\begin{tabular}{|c|c|c|c|}
\hline Kekuatan (Strength) & \begin{tabular}{|l} 
Weakness (Kelemahan) \\
\end{tabular} & $\begin{array}{l}\text { Opportunity } \\
\text { (Kesempatan) }\end{array}$ & Threats (Ancaman) \\
\hline $\begin{array}{l}\text { 1. Banyakkaryawanyang } \\
\text { sudah bisa mengkases } \\
\text { sistem ini dengan } \\
\text { menggunakan mobile } \\
\text { android perangkat } \\
\text { bergeraknya. } \\
\text { 2.Perusahaan mempunyai } \\
\text { infrastruktur intemet } \\
\text { yang semakin cepat } \\
\text { untuk transaksi data pada } \\
\text { web } \\
\text { Application. } \\
\text { 3.Perusahaan memiliki } \\
\text { web application dan } \\
\text { database server untuk } \\
\text { menajalankan usahanya. }\end{array}$ & $\begin{array}{l}\text { 1. Keamanan ristem } \\
\text { berbasis web masih } \\
\text { memiliki r celah } \\
\text { keamanan. } \\
\text { 2.Fungsi sistem cuti } \\
\text { karyawan yang dapat } \\
\text { diakses dengan mobile } \\
\text { android masih belum } \\
\text { banyak karyawan yang } \\
\text { mengetahuinya. }\end{array}$ & 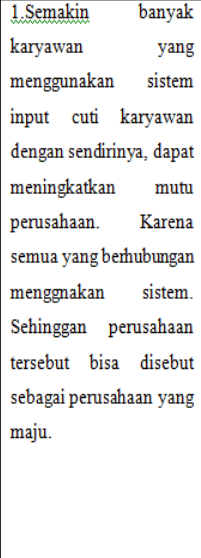 & $\begin{array}{l}\text { 1. Data karyawan dapat } \\
\text { diakses oleh pihak yang } \\
\text { tidak berkepentingan. } \\
2 \text {.Perlunya tingkat } \\
\text { keamanan yang tinggi } \\
\text { pada sistem ini agar pada } \\
\text { sistem ini tidak dapat dir } \\
\text { etas maupun bocor untuk } \\
\text { data-datanya. }\end{array}$ \\
\hline
\end{tabular}

A weakness of this system is when there is a doctor's schedule change because the doctor is unable to attend or due to something sudden, then this becomes an obstacle that must be resolved by IT administrators. The administrator must change the doctor's schedule on that day and automatically patients who have already registered will be replaced by another doctor on the check-up date.

\section{CONCLUSION}

At the end of this pentup is made in the form of conclusions and suggestions, namely as follows: From the results of the research on the application of the employee leave input system, the authors conclude the following: 1 . The online leave system created can simplify the leave submission and approval process. With an online leave system, the process of submitting leave proposals can be done without having to meet face to face. 2 . With the online leave application, employees are expected to receive more information about employment, especially the issue of leave, leave proposals can be made without having to meet face to face in person. 3. With this system it can also improve the performance of human resources at the company. In order to improve the function of the online leave system as a service and dissemination of information, further developments that can be done from this thesis include: 1 . Improve the appearance (interface) of the online leave system so that it is more attractive and easy to use. 2 . Provide a stronger security system for the network by using the WEP and WPA encryption systems. 3. Increase the internet speed network at the company so that the system can speed up work. 
International Journal of Computer and Information System (IJCIS)

Peer Reviewed - International Journal

Vol : Vol. 02, Issue 01, February 2021

e-ISSN : 2745-9659

https://ijcis.net/index.php/ijcis/index

\section{REFERENCES}

[1] Gunawan, Wahyu. 2010. Kebut a day to be a PHP master. Yogyakarta. Publisher Genius Publisher.

[3] Gregorius, 2000 : 30. https: //www.gurupend Pendidikan.co.id/pengentuk-website/

[4] Gunawan, Wahyu. 2010. Kebut a day to be a PHP master. Yogyakarta. Publisher Genius Publisher.

[5] Gunawan, Wahyu. 2010. Kebut a day to be a PHP master. Yogyakarta. Publisher Genius Publisher.

[4] Hermawan, Julius. 2005. Building a Decision Support System. Yogyakarta: Andi.

[5] Grace. 2007. Introduction of SQL. From http://rahmat.polinpdg.ac.id/content/view/62/64/. 10 June 2010.

[6] Muqorobin, M., \& Rais, N. A. R. (2020). Analysis of the Role of Information Systems Technology in Lecture Learning during the Corona Virus Pandemic. International Journal of Computer and Information System (IJCIS), 1(2).

[7] Muqorobin, M., Kusrini, K., Rokhmah, S., \& Muslihah, I. (2020). Estimation System For Late Payment Of School Tuition Fees. International Journal of Computer and Information System (IJCIS), 1(1).

[8] Solihin, Ahmad, MySQL 5 From Beginner to Advanced, Achmatim. net. Jakarta. https://www.firebase.com/features.html, accessed September 26, 2015.

[9] Muqorobin, M., Rokhmah, S., Muslihah, I., \& Rais, N. A. R. (2020). Classification of Community Complaints Against Public Services on Twitter. International Journal of Computer and Information System (IJCIS), 1(1).

[10] Muqorobin, M., \& Rais, N. A. R. (2020, November). ANALISIS PERAN TEKNOLOGI SISTEM INFORMASI DALAM PEMBELAJARAN KULIAH DIMASA PANDEMI VIRUS CORONA. In Prosiding Seminar Nasional \& Call for Paper STIE AAS (pp. 157-168).

[11] Utomo, I. C., Rokhmah, S., \& Muslihah, I. (2020). Web Based Distribution of Zakat, Infaq, and shodaqoh (Case Study Of Surakarta City Region). International Journal of Computer and Information System (IJCIS), 1(1).

[12] K. Kusrini, E. T. Luthfi, M. Muqorobin and R. W. Abdullah, "Comparison of Naive Bayes and K-NN Method on Tuition Fee Payment Overdue Prediction," 2019 4th International Conference on Information Technology, Information Systems and Electrical Engineering (ICITISEE), Yogyakarta, Indonesia, 2019, pp. 125-130, doi: 10.1109/ICITISEE48480.2019.9003782.

[13] Muqorobin, M., Hisyam, Z., Mashuri, M., Hanafi, H., \& Setiyantara, Y. (2019). Implementasi Network Intrusion Detection System (NIDS) Dalam Sistem Keamanan Open Cloud Computing. Majalah Ilmiah Bahari Jogja, 17(2), 1-9.
[14] Muqorobin, M., Apriliyani, A., \& Kusrini, K. (2019). Sistem Pendukung Keputusan Penerimaan Beasiswa dengan Metode SAW. Respati, 14(1).

[15] Abdullah, Robi W., et al. "Keamanan Basis Data pada Perancangan Sistem Kepakaran Prestasi Sman Dikota Surakarta." Creative Communication and Innovative Technology Journal, vol. 12, no. 1, 2019, pp. 13-21.

[16] Saputra, R., \& Rais, N. A. R. (2020). Online Sales System Analysis of PT. Nutrifood Indonesia through the distributor CV. Trio Sukses Mandiri Solo With Nutrimart Home Delivery (NHD) Application. International Journal of Computer and Information System (IJCIS), 1(2).

[17] Muslihah, I., Muqorobin, M., Rokhmah, S., \& Rais, N. A. R. (2020). Texture Characteristic of Local Binary Pattern on Face Recognition with PROBABILISTIC LINEAR DISCRIMINANT ANALYSIS. International Journal of Computer and Information System (IJCIS), 1(1).

[18] Hikmah, I. N., \& Muqorobin, M. (2020). Employee Payroll Information System On Company Web-Based Consultant Engineering Services. International Journal of Computer and Information System (IJCIS), 1(2).

[19] Nastura, S. A., \& Muqorobin, M. (2020). Transaction Processing System Analysis Using The Distribution Management System (DMS) Nexsoft Distribution 6 (ND6). International Journal of Computer and Information System (IJCIS), 1(2).

[20] Muqorobin, M., \& Rais, N. A. R. (2020). Analysis of the Role of Information Systems Technology in Lecture Learning during the Corona Virus Pandemic. International Journal of Computer and Information System (IJCIS), 1(2). 